\title{
カーシェアリング社会実験の現状と 導入に向けた計画手法の課題
}

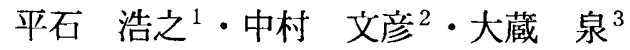 \\ ${ }^{1}$ 正会員 博士（丁学）（株） 日本能率協会総合研究所 社会環境研究本部（テ105-0011 東京都港区芝公園 3-1-22） \\ E-mail : hiroyuki_hiraishi@jmar.co.jp \\ 2 正会員工博 横浜国立大学大学院教授 環境情報砶究院 （广240-8501 横浜市保土ケ谷区常盤台 79-7） \\ 3 フェロー会員 工.博 横浜国活大学大学院教授 工.学研究院 （T240-8501 横浜市保士:ヶ谷区常盤台 79-5）
}

\begin{abstract}
2002 年末までに日本国内で取組まれている自動車共同利用, つまりカーシェアリングのうち 11 地区. 12 プロジェ クトを刘象に導入都市概況，運用システム，実験規模などを整理した．またこれら実験での成果から，今後の事業 化の検討や，交通計画での導入判断に必要と見込まれる段階的な需要予测方法，実際の運用での効率化に資する運 用方法，デポ規模について，利用者要望，利用実態を踏まえつつ提案した．また実験時のコストは特殊状況のため 厳密な運用コストが把握できていない点は課題である. 高質な公共交通, 高い人口密度の点から, わが国における カーシェアリングの潜在需要は十分あり，限られた条件で得られた結果のみから本格導入時の採算性などを安易に 判断することなく，総合的な視点で導入に们けた計画手法の確立，制度の改善が進むことが望まれる.
\end{abstract}

Key Words: car sharing, shared-vehicle, pilot project, rental-car

1.はじめに

\section{(1) 研究背景}

自動車共同利用（カーシェアリング）は，駐車場 用地制約やコスト制約により, 自動車の導入負担が 高い地域における自動車利用の効率的な導入策, 高 コストの低公害車導入支援策等として, 欧米を中心 に近年注目されている方策である.わが国において も, 1990 年代後半から各所での実証実験や社会実験 が続けられてきた. 2002 年からはカーシェアリング をまたる業とする民間株式会社, 非営利団体が起業 する一方で, 電気自動車, 低公害車に特化したレン タカー会社が破綻するという厳しい状況もみられる. 全体としては本格実施段階に入りつつあるものの, 事業性の点で多くの課題を残すといえる.

海外での普及傾向もあり, NPO を中心に本格実施 への機運は高まりつつある. 実際の事業化に対する 公的支援体制や支援制度の整備は，実施された社会 実験や実訨実験に比し進んでいない。これは, カ一 シェアリングに関わる学術的な研究が進みつつも, 事業判断や行政判断を行う上での基礎的な需姴予测 や運用効率, 費用対効果についての把握や手法確立. が十・分でなく，施策実施者や事業運用者の決断を促 すまでに至っていない事が一因と考えられる.

\section{(2) 研究目的亡研究構成}

よって本論文では，本格的なカーシェアリングの
展開に向けた実務的な課題を明らかにするため，報 告書入手やヒアリングなどが行えた国内での社会実 験の成果の横断比較を基に，北米欧州での先進実施 例も参考にしながら本格実施に向けた需要予測など における課題, 実務的な必要条件, 今後の研究課題 などについて整理を行う.

\section{2.カーシェアリング取組み状況}

\section{（1）システム分類と用語定義}

自動車共同利用システムは, 導入地域が都市部か 住宅地か郊外駅周辺か, 主な対象需要が地域住民か 企業か, 両者混合かなどから表-1のように区分する ことができる.

欧米において拡大傾向にあるのは, 都市部の業 務・居住近接地域や都市近郊部の居住地域において 駐車場コスト，自動東保有コスト双方の削減できる

表-1 自動車共问利用の分類

\begin{tabular}{|c|c|c|}
\hline $\begin{array}{l}\text { システム名称 } \\
\text { :別名など }\end{array}$ & $\begin{array}{c}\text { 吾入地城 } \\
\text { （主な曼け洨し場所） }\end{array}$ & 主な対象政要 \\
\hline $\begin{array}{l}\text { シティーカー(部市型) } \\
\text { シティーレンタカー }\end{array}$ & $\begin{array}{l}\text { 主に都心部·市膚地 等 } \\
\text { (事萧所 策約地) }\end{array}$ & $\begin{array}{l}\text { 日中茦務利用 } \\
\text { 都市部内 居住者利用 }\end{array}$ \\
\hline $\begin{array}{l}\text { 郊外住宅地 } \\
\text { カーシェアリング } \\
\text { :セカンドカー第 }\end{array}$ & 郊外住宅地など & 日中買物利用 など \\
\hline $\begin{array}{l}\text { エコ・パークアンドライト } \\
\text { :ステーションカー }\end{array}$ & 郊外通勤黔周辺 & $\begin{array}{l}\text { 朝夕:逼䡃㛿宅 } \\
\text { 日中: 莱務利用 }\end{array}$ \\
\hline
\end{tabular}


利点を重視した“シティーカー”つまり”都市型自 動車共同利用”である. 日本においては，郊外居住 地でも自敷地内での駐車場用地, 特に 2 台目需要に 対応する用地確保困難性から“郊外住宅地力ーシェ アリング”のニーズも欧米に比べ高いといえる.

また郊外でも，駅前や駅近接地に業務集積が-定 規模ある場合，通勤者の駅端末の交通手段や日中の 業務利用者との間で共同利用する “エコ・パークア ンドライド”,アメリカではステーションカーと呼ば れる方式は, 利用効率性と収益性の 2 点から注目さ れるものである. 海外に比して，郊外と都心とを結 ぶ鉄道サービスレベルの高く，郊外でも駅周辺に業 務施設が立地する場合が多い日本では，特に効果を 発揮しやすいシステムである。

運用主体が管理する貸出返却場所の区分では，実 質 1 籄所か， 複数筒所かで区分され，後者について は“マルチデポ”型と言う。さらに利用可能な借出 し返却方法として次の区分がー般的に言われている. 主に利用時の発着場所に対する分類であり，借出し 場所と返却場所が同一である “ラウンドトリップ” 型と，借出し場所と返却場所が異なる “ワンウェイ トリップ”型である. 当然ながらワンウェイ型はマ ルチデポである事が条件となる.

\section{（2）国内事例と咱入都市概要}

社会実験や実証実験が中心である日本でのカー シェアリングの取組みを 2002 年度末までの奏施状 況で整理した。整理対象としたのは，一般の市民や 企業の参加が可能で公道を走行する実験であり, 2003 年 5 月時点で報告書入手, または直接ヒアリン グにより運用状況が確認できた 11 地域, 12 プロジェ クトである．9プロジェクトが電気自動車のみを用 いてのもの，2プロジェクトがガソリン車のみ， 1 プロジェクトが電気自動車とガソリン車の併用と なっている. 表- 2 に, システム分類と貸出時の運用 方法を, 表- $3 に$ 各実験の概要について示す. 表のう ち, 要知県豊田市の 2 プロジエクトは実験運用に重 複する部分が多いが，実施主体が 2 団体あり異なる プロジェクトとして行われている，電気自動車での

表-2 社会実験実施地域とシステム分類

\begin{tabular}{|c|c|c|c|}
\hline 莫出造却 & シティーカー & カージ外宅地 & エコ・バークアンドライド \\
\hline ラウンドリッフ & 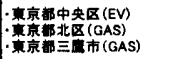 & 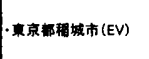 & 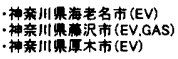 \\
\hline $\begin{array}{l}\text { ラウンドリッフ } \\
\text { +ワンウェ1 }\end{array}$ & 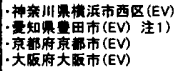 & ----- & --- \\
\hline
\end{tabular}

注1）豊田市は異なる夹施主体が2つある。

注 2 ) EV:電気自動車, GAS : カソリン車 を利用

注 3 ) 2002 年 8 月末時点での整理
実験が中心となっているのは，噮境対策として行政 支援を受けやすいことも影響している，充電施設の 設置負担はあるが, 共同利用の管理面で連用時の燃 料費用の管理手間を削減できる.ガソリン車の場合， 給油を誰が行うか, 利用者が行う場合, 領収処理を どのように行うかの点で課題があり, 国内の車雨共 同利用では利用が進んでいなかった部分である.

これらの社会実験はITS の開発進展, 環境対策一 環の低公害車車両導入支援の一つとして検討されて きた経緯があり, 最も取組みが早いプロジェクトで は, 1999 年末から実験運用が開始され, 長期に渉り 段階的に実験規模や方策の拡大が行われてきている.

実験に取組んだ都市の規模は, 表-3に示すように 主導入地での行政人口規模 10 40 万人程度が中心 となり, 業務機能が中心の大都市都心区では, 行政 区人口で 10 万人を下回る場合もある.

図- 1 は縱軸に主導入地の行政単位人口密度, 横軸 に地域内の高層建築最高階数を, 地域の業務密度や 土地収益性での地価の高さ, 駐車用地確保困難性を ある程度反映する代替指標と仮定し作図した。

人口密度では 6 千人 $/ \mathrm{km}^{2}$ 以下の主に郊外地域, 9 千人 $/ \mathrm{km}^{2}$ 以上の大都市都心部地域に分かれる. 人口密度と建物最高階数の関係で分布をみると, 多 様な都市環境中, まだ限られた地域条件での実験で ある. 居住人口, 業務密度ともに高い大都市中心部 の横浜市, 大阪市中心部と, 人口密度は高いが業務 密度は中規模の東京都周辺区市及び京都市内, 人口 密度, 業務集中とも中規模程度で郊外都市の 3 地域 に分かれる.なお東京都中央区は高層住宅に付帯す るもので, 他の実験地域とやや導入環境が異なる.

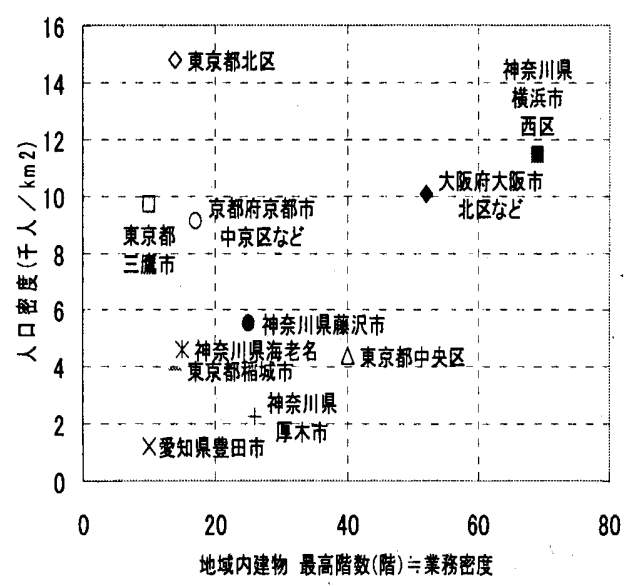

図-1 社会実験地域の地域内建物階数と人口密度 注）人口密度は主たる貸出返却駐車場が立地（主導入地）して いる行政地の人口, 面積より算定 


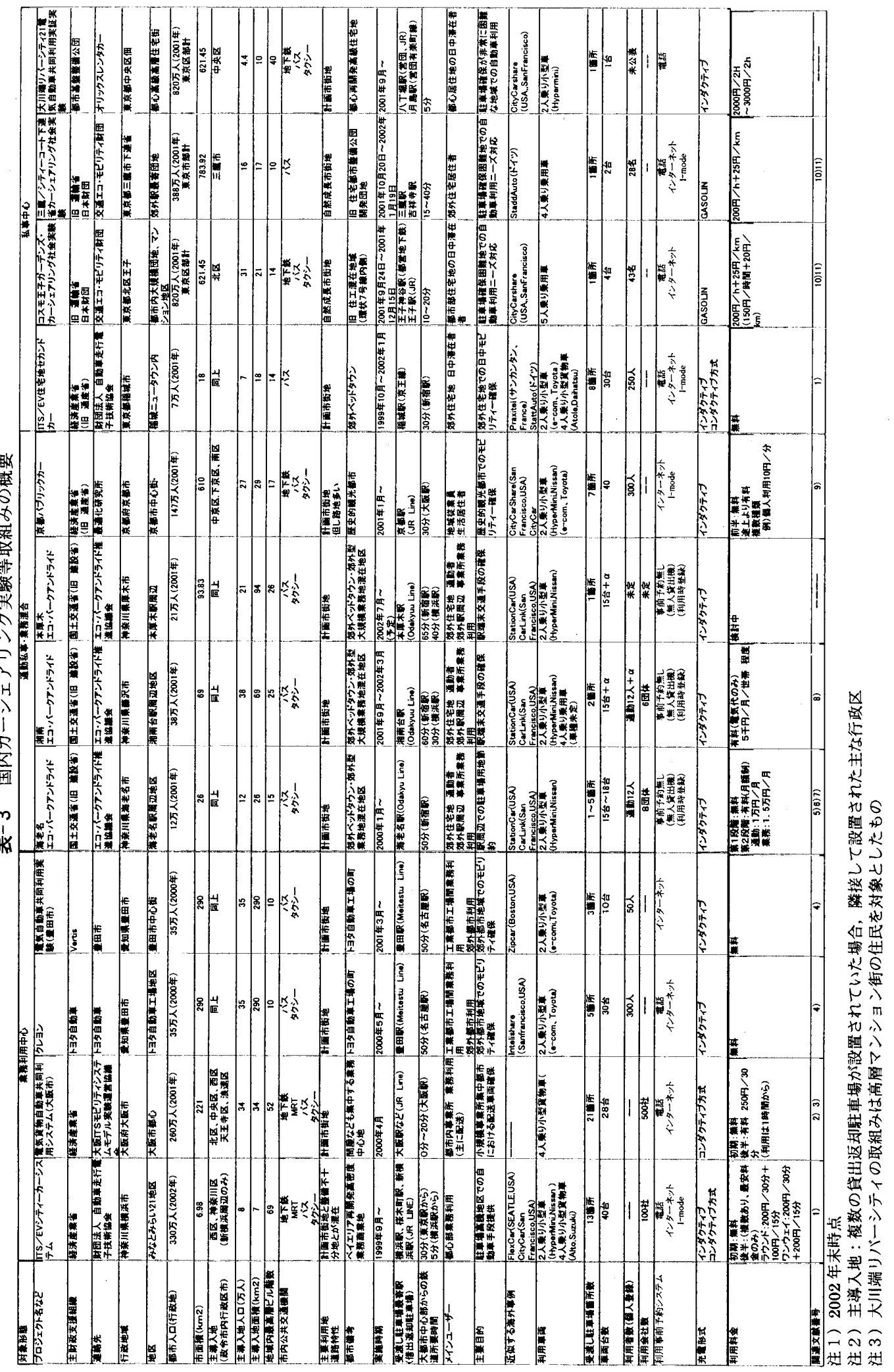




\section{3 . 自動車共同利用の需要推定課題}

\section{（1） 5 段階の需要推定}

2002 年までの実験を踏まえ, 冒頭に紹介したよう な事業化への取組みが進みつつある。 また，欧米並 みに車両共同利用の導入が進めば，交通計画を担う 行政機関にとり，駅周辺の交通計画などの場面で将 来計画に組み込む必要があるかなどの判断が求めら れる可能性もある. 車両共同利用の導入では, 鉄道 の新設などに比べ事業に必要な初期費用は少ない. それでも，事業実施者にとっては，複数台の自動車 購入, 貸出管理機器の確保, 駐車場の手配などある 程度の資本が必要なことから，事前に提供を予定す るサービス水準に応じ，利用者数，それに伴う事業 採算性, 導入後の地域交通への影響を予測できるこ とが今後必要になってくると考えられる.

自動車共同利用の需要推定については，恒常的交 通インフラとしての特性と, 市場に出回る周知率の 低い新製品としての 2 つの要素を持つ. 従来の道路, 鉄道は新規整備でも一定の期間が経てば，ほぼ $100 \%$ の周知が期待でき，沿線人口などの要因から 説明される将来交通需要を予測すれば，ある程度導 入後の利用量を予測できた.

しかし現段階の車両共同利用では，システム自体 の周知が低い点, 鉄道, バスに比べ小回りのきく交 通手段であるがゆえ，導入条件の差が，大きく利用 者の增減に関わる点など，鉄道の需要予測などに用 いられてきた需要推定方法のみでは，事業判断に必 要となる確度の高い利用が把握し難い.

このため, 需要の推定にあたっては, 導入を想定 する段階に応じて,

・段階 1 広範因な潜在需要

サービス水準は未定の状況で，都市圈などで
の需姴を推計する.

・段階 2 実質的な最大需要

サービス水準, 具体導入地などが明確な下゙で, 諸要因を考慮し需要を推計する.

・段階 3 需要の顕在化速度

段階 2 で推計された実質的な最大需要が周知 の向上やサービスのレベルにより，どの程度の 速さで顕在化するか.

・段階 4 実利用需要 (1人あたりの利用量も含む) 利用者の属性，地域環境，料金水準などから 推計される日あたりの利用回数や 1 回あたりの 利用時間などの推計。

・段階 5 退会率

利用需要として顕在化したのち，転居，業務 環境の変化, ライフスタイル変化などにより利 用会員から脱会する比率.

の 5 段階で, 表- 4 に示すような内容のデータなどを 用い，それぞれ推定方法が確立される事で, 事業計 画などへの反映が出来るようになる.

\section{（2）潜在需要と実的な最大需要}

従来の交通機関での検討に近い段階 1 , 段階 2 お ける潜在需要, 実質的な最大需要の推計ついて, 需 要推定方法やその考虑すべき要因についての研究は 途上である. 導き出される推計值は, 特に行政団体 の将来交通計画における政策判断や，事業額の検討 に寄与する重要な量である.この段階までについて は，市民の通勤利用を対象とし選好意識調查を基に した吥究 ${ }^{5)}$ や, 任意の条件により P Tデータより利 用可能性のある規模を推定した研究 ${ }^{6) ， 12) ~ か ゙ あ る . ~}$ ただし害務利用での整合性や補正の必要性について は，まだ課題を多く残す。

また，業務利用を対象とする場合の需要推計につ

表·4 自動車共问利用の需要推定段階（案）

\begin{tabular}{|c|c|c|}
\hline 需要推定の段階 & 概要 & 主な母集団データ \\
\hline 1. 広範再な潜在需要 & $\begin{array}{l}\text { 都市状況，交通施設サ一ビス状涗を要因として推定 } \\
\text { される潜在需要 }\end{array}$ & $\begin{array}{l}\text { ·地域人口 } \\
\text { ・パーソントリソプOD } \\
\text { ·道路交通センサスOD } \\
\text { 大都市通センサス駅端末手段交通別量 } \\
\text { など }\end{array}$ \\
\hline 2. 实質的な最大需要 & $\begin{array}{l}\text { 提供システムの駐車場位置，料金などのサービスし } \\
\text { ベル条件が明示されたももと顥在化する期待会員数 }\end{array}$ & $\begin{array}{l}\text { ·事業所数 } \\
\text { 事莱所従業員人口 } \\
\text { ·敒乗降客数 } \\
\text { ·道路交通センサスOD } \\
\text { なとと }\end{array}$ \\
\hline 3. 需要の顕在化速度 & $\begin{array}{l}\text { システム実施後，利用者数が安定期間に入るまでの } \\
\text { 会員数の伸び度合い } \\
\text { 埇量や実施規模により推定できることが望ましい }\end{array}$ & 2. で推計された会員数など \\
\hline 4. 実利用需要 & $\begin{array}{l}\text { 実際の会員登録後の利用回数や利用頻度, 利用OD } \\
\text { 距離など }\end{array}$ & $\begin{array}{l}\text { ·登録会員数 } \times \text { 社会実験での実績 } \\
\cdot \text { 登録会貝数 } \times \text { 各種分布系の当てはめ } \\
\text { など }\end{array}$ \\
\hline (5. 退会率) & $\begin{array}{l}\text { 転居や車両の新規購入などによる自動車共同利用 } \\
\text { 会員からの脱会数など }\end{array}$ & ·登録会員数の変化 \\
\hline
\end{tabular}


いては, 各実験とも模索的にモニター企業を集める 取組みが中心であり, 潜在需要の推定方法や原単位 などについては明らかにされていない，大阪市 2).31 や京都市の実験報告からは, 会員登録はするが利用 はしない “未利用会員” 問題があり, 実験での登録 のあった会員属性が汎用的な利用需要推定に適用可 能かの点で, まだ判断が難しい.

\section{( 3 ）需要顕在化の速度}

従来, 公共の関与度合いが深い交通インフラ分野 では, 事前の予測需要に達するまで, ある程度長期 にわたり待つことが出来た.これに比べ，主に民間 事業者に運用を期待するカーシェアリングでは，段 階 3 の需要の顕在化速度, つまり本格実施開始から どの程度の需要が獲得出来るのか, 一定期間の問に どの程度の需要の伸びが期待できるのかが事業上重 要となる.この点で予測が確立できないと, 十分な 投資判断や事業実施判断が行い難く, 特に周知率が 低く, 会員数の少ない初期段階登録者のみの限られ た情報の中で, 事業継続性が判断される危険がある.

予測方法の確立には, 事業取組みからデー夕を蓄 積していく方法と, 他の周知が低い製品の普及速度 モデルを適用して検討していくことが考えられる. ただし後者については, カーシェアリングに対して どのような先行商品に類似性があるのか定義が難し く, その検証自体が一つの大きな課題となりうる.

\section{(4) 実利用需要 (利用量)}

段階 4 で必要な利用回数や利用時間の予測につい ては, 国内 12 実験での実績を基に推計方式を確立. することも考えられる.

大半の実験では, 開始当初の運用形態として無料 利用, ラウンドトリップでの利用を中心に始め, 一

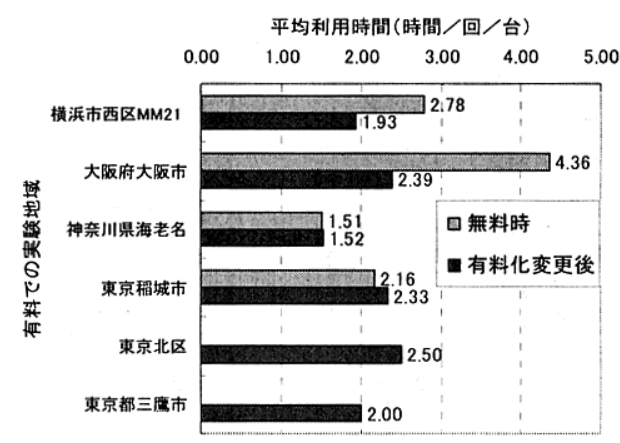

図-2 有料化前後での平均利用時間 注 1 ) 海老名市は月額固定料金 注 2 ）北区, 三鹰市では実験開始時から有料
定期間の実験後に部分的なワンウェイトリップの利 用, 部分的な有料化の開始と段階的に実験拡大を行 う取組みをとってきた.

当初から有料の実験が多い海外の実験に比し, 日 本では有料実験での取組みは遅い。これは実験当初 からカーシェアリングに関わる法制度, 特に受け渡 し時に管理者の立会いが無い状態で運用を行って良 いのか明確な判断が無かった点, 業としてレンタ カ一事業登録の無い団体や任意組織が利用料に相当 する収益を得て良いかの行政判断が明確に無かった 点などが影響している.このため 2000 年中期まで の実験は，いずれも募集した利用会員に無料で共同 利用を行ってもらう体験利用となっていた.

無料期間においては, 利用時間や距離の增加に応 じて料金負担の增分を意識する必要が無く，車両の 借出しを実際の利用よりも長時間確保する例, 返却 時間を越えて返却する例, 利用の有無に関わらず予 約を行う例などが各実験で報告されている. 図-2に あるように，利用時間に応じた料金制を導入し業務 利用を対象とした横浜市, 大阪市の実験では有料化 後に大きく利用時間が隇少する傾向となっている. 利用時間の変動が少ない稲城市の場合 ${ }^{1)}$ にも, 実際 は前年度の無料時の登録会員数約 240 人から有料へ の移行時は 20 数人と, 10 分の 1 まで会員数が減少 した. 稲城の主な利用対象は日中住宅団地に滞在す る主婦, 無職層であったため, 料金支払いに対する 抵抗感が大きかったことも影響していたと思われる また利用時間以外にも利用回数の減少も報告されて いる. よって, 無料提供で得られた条件を基に, 配 車や採算性の検討を行うことには多くの課題を含ん でおり, 本格導入で有料化に至った場合の減少率を 一意的に求める事も, 導入地の環境, 駐車場の配置, 運用対象時間など複合的に関係すると見られ, 現状 では困難である.

この点では需要顕在化速度と同様に, 先駆的な事 業取組みでの実績を基にデー夕を蓄積し, 早い段階 で推計方法を確立できる必要がある.

\section{（5）退会率}

最後に, ある程度発生が見込まれる退会の割合が 段階 5 として必要となる. 現段階の社会実験では本 格実施を想定した有料化運用に変更後, 会員応募数 の著しい減少, 会員数の脱退という問題も抱えてき た. モニターとして利用を開始した利用者も, 長期 的な事業の継続性が確約されていない事を理由とし 利用継続されない場合が多い。本格実施に至った場 合でも, ライフスタイルの変化や, 就業環境の変化 で一定の割合で退会が発生することを想定できれば, 
より事業計画が立てやすくなる.このため段階 5 で は，このような実態も踏まえつつ，退会がどの程度 起きるのか事前に予测する必要があるが, 社会実験 や実証実験での利用者属性と利用継続実態からは, まだ現場で実用性のある推計モデルを確立するに 至っていない.

\section{4. 運用の効率化}

\section{（1）ママルチデポ方式での実験成果}

都市部でのカーシェアリングとしては, 駐車場ス ペース問題の解消, 自車保有に制約されない柔軟な 交通移動が可能になる, 先進の低公害車などコスト が高い車であっても共同利用で導入コスト負担を軽 減できる可能性もあり, 多様な点からマルチデポで ワンウェイも可能とするシティーカーシステムが将 来の理想系といえる. また利用喚起と利用者利便性 の面からもマルチデポ運用でのサービス提供は, 重 要な要素であると考えられる.

この運用形態では豊田市 ${ }^{4}$ )，横浜市みなとみらい 21 地区 ${ }^{2}$, 大阪市内都心 ${ }^{22.3)}$, 京都市内 ${ }^{9)}$ で実験が 行われている.これらの実験では, マルチデポとし ての機能を最大限発揮する事を狙い, 部分的なワン ウェイ方式の導入から段階的に広範なマルチデポの 実験に至っている．鉄道路線密度の低い豊田市での 実験を除き, 残り 3 地域では各所の鉄道駅周辺にも デポを確保して運用実験が行われている.

都市部 3 箇所 1)，2，3) での実験から，利用者が望 むワンウェイ運用を実現させる事は，時間帯による OD 方向の偏り，これに伴う行き先駐車場の受入駐 車場所確保が問題とされている. 特に余剩駐車場の 確保必要性の增大，駐車場確保が困難な場合には駐 車場間で車両の回送，再配車に伴う労働力およびコ スト負担の增大が問題となる.

通常，ワンウェイでの利用ニーズが集中する鉄道 駅近くの駐車場確保には, 市街地での平均的な駐車 費用より割高な費用負担が必要となる. 駅至近の駐 車場の確保は, 運用者にとりシステム魅力の向上に よる利用者增が期待できつつも, 運用コストの大幅 な上昇を招きかねず，費用対効果の部分で困難な選 択を迫られる部分である.

実験では，ワンウェイの利用希望に対し，予約シ ステムで行き先駐車場の空き有無を事前または利用 希望後にチェックし, 借出し受付チェックを行って いる. この場合, 車が空いていても希望先の駐車場 に空きが無ければ利用予約受付が行えない方式であ る.このようなシステム運用は，利用できない場合 の利用者の満足度を著しく下げる事となる。一方で
実際の利用者へのヒアリングからは, 都心部の隣接 駅間程度の距離であれば, 運転中は貸出返却駐車場 までの移動時間は気にならないとの指摘もある.

岡 ${ }^{15)}$ によれば，ヨーロッパの都市内自転車共同利 用の実験で地域内に複数のデポを用意し, 借出し時 に返却先を指定するシステムをとった例がある.こ のシステムでは, 借出し時に目的地として指定され た駐輪スペースに空が無くても, 周囲の駐輪場を割 引料金で示し, 利用を促す方式をとっている. これ により, システム運用者は, デポ間での回送負担を 削減でき, 利用者は目的地までの最善では無いが, 自ら選んだ妥協できる交通手段と経路を選択して移 動が可能となるのである.

\section{（2）マルチデポの運用方式と最適化検討への提案}

実験などを踏まえたマルチデポ方式，ワンウェイ 運用のモデル化, 効率化の検証については, 運用最 適化のシミュレーションや配車検討 ${ }^{4)}$ ，5)，6) として 㼋究が進んでいる.

実験での傾向, 岡の紹介システムなども参考にす ると, カーシェアリングのマルチデポ運用段階では 固定 OD で利用予約の受諾可否を決定するよりも, ヨーロッパの都市内自転車共同利用での取組みに見 られるよう,一定エリア内のデポの空情報を提供し， 利用者の意思で OD または経路がある程度の範用で 変更される可能性を考虑するほうが, 事業運用者に とり必要かつ現実的なシステムである. 特に鉄道駅 間が短い都市部の場合, ターミナル駅の最寄りだが, 徒歩では遠い駐車場を選ぶより，一駅離れても駅に 近接する駐車場の方がトータルでの利用者利便性が 高まる場合もある. この種の運用方法が運用側, 利 用側双方にとり，さらに望ましいシステムと考えら れる.

この点については, 図 - 3 のような選択を含んだ $\mathrm{SP}$ 調查などから利用者の選択, 評価構造を明らか にし, 運用最適化, 効率化の研究において, 運用方 法の追加条件やケースの一つとして加えてもらい, 実際の運用システムに反映される事が望ましい.

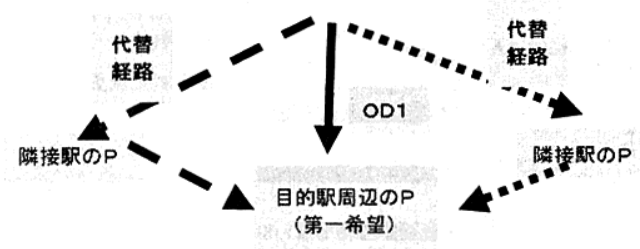

図-3＼cjkstart複数デポと鉄道路線の融合運用 


\section{（3）箇所あたり配置台数}

まとまった台数分の確保は都市部駐車場ではコス 卜，空き状況の両面から困難を伴う。実利的な貸出 返却用駐東場の確保方策として，貸出デポでの配賢 台数としては，駅に近く条件の良い駐車場に多数台 の確保を行うより, 駅周辺の立地条件が異なる複数 駐車場に $1 \sim 3$ 台程度の容量で確保する方式も考え られる。

神奈川県海老名市 7)で通勤利用者の帰宅時を対象 に行った奏験では，単独駅の周りに距離や立地条件 の異なる 5 箇所のデポを設置し，駅前で空き駐車場 の情報提供を行い, 利用者が任意に持ち出しデポを 選択できる方式を試みた。この実験では，利用者側 が任意の判断で空き駐車場を選択し，必ずしも第一・ 目的の駐車場に拘らないとの結果が示されている. さらに条件の悪い駐車場に返却する場合，料全差が あれば容認して利用するとの指摘もされている.

利用者側からの視点では，1箘所であっても良好 なデポがあれば利用システム評価の向上に慗がり， 運用者側にとっては実際にデポの確保, 維持に必要 となる過大なコスト增加の抑制, 駐車場確保の容易 性の向上，また駐車場によってはコイン式無人駐車 場を活用できるなどで導入可能性が広がる。このよ うに 1 筒所の駅周辺でも少台数, 複数箇所駐車場で の運用を想定した計量的な需要予測や, システム最 適化分析が行われることが今後必要と考芫る.

\section{5．実験時コストを踏まえた事業採算性}

日本でのカーシェアリングは低公害車, 特に電気 自動車普及策や ITS 活用策としての検討開始が多 かったため, 前出の社会実験でも 2 地域の例を除き 電気自動車のみを利用している。この結果, 各実験 地域では車両の多様性, 特に乗本定員別での選択自 由性が限られていた。

各実験後の事業化の判断段階では, 電気自動車お よび充電器など周辺機器は開発段階のものを用い, 人的管理体制も実験に限った専従体制であったなど， 計上するコストの定義があいまいな部分が多い。こ のため事業採算性を評価していても，本格事業まで の不確定要素が多く，十分な評価にはなり難い。ま た，実際の事業化に至っているアメリカのシアトル やカナダのトロントでの例では, 乗用車からピック アップトラックまでを揃え，1車種あたりの台数は 多く無いが, 全体としては車種の選択幅が広く利用 者满足の向上が図られている.つまり, 実際の事業 を見すえた場合, 車種多様化での顧客誘引効果も見 すえつつ, 事業性の評価を行える事が望ましい.

\section{6. まとめと今後の課題}

\section{（1）まとめ}

本稿では 2002 年度末までに実施された,カーシエ アリングの社会実験など 12 取組みを対象に導入都 市概況, 運用システム, 実験規模などを整理し, 都 市人口特性などとの比較を行い, 国内の都市の中で は限られた都市条件での取組みである点を確認した。

またこれら実験での成果から, 今後の事業化の検 討や, 交通計画での導入判断に必要と見込まれる段 階的な需要予測方法, 実際の運用での効率化に資す る運用方法, デポ規模について, 利用者要望, 利用 実態を踏まえつつ提案した．また実験時のコストを 基にした事業採算性の評価については，海外の本格 導入例で車種多様化の場合が多いのに比し，わが国 の実験では単-·車種，電気自動車中心である点，実 験という特殊状況のため厳密な運用コストが把握で きていない点を課題として整理した.

\section{(2) 今後の課題}

複数の専業事業者の設立があり，国内のカーシェ アリングは実験段階から，交通システムの・つとし て本格導入，展開に向けた段階への過渡期にある.

現時点までの取組みはITSの進展が先行したシス テム重視型や，理念先行型であった点は否めない． 実験予算も単年中心の行政支援に大半を頼るため, 一度会員になった場合も，年度を越えた時点で数ヶ 月以上の休止期間が生じ，再度会員募集を行う例が あるなど永続的な交通インフラとしての評価が難し い状況にある．このように限定的な条件の下に得ら れた結果から本格実施の可否が判断されることは, 1980 年代に東京都練馬区で開始され, 導入機運が高 まりつつも，それ以降目立った展開とならなかった 都市型レンタサイクルの経緯を辿る恐れがある.

アメリカ, ドイツなど諸外国の都市では，人口密 度が低く, 駐車場確保も容易, 公共交通網整備は十 分で归いなどマイカーに依存しやすい環境下ながら, カーシェアリングの導入が広がった。わが国の都市 部の環境は, 高密度な居住地, 業務集積により需要 密度が高い，地価の高さを背景に駐車場コストが非 常に高く車の保有コストが高い, 古い団地や住宅地 を中心に慢性的に駐車場不足の地区を多く持つ，治 安が良く無人借出返却時のトラブル可能性が低い, 近隣の都市間移動でも高質の鉄道サービスにより直 行移動での車の速達優位性は低いなどがある．つま りカーシェアリングが活用される好条件が揃ってお り，普及対象となる潜在需要も十分あるといえる. ただし社会実験の段階では，環境配慮先進国に比 
ベれば市民レベルの噮境意識がまだ低い，都市部で は無料駐車場も殆ど無くシェアリング費用に加え駐 車場費分の割增感が起きやすい, 駅端末としてバス がある程度機能しているなど, 幾つかカーシェアリ ングの優位性を発揮できない部分もある. 多大な費 用を要した実験成果が必ずしも期待通り得られてい ない要因の一つである.また事業化に必要な法制度 の解釈, 行政が支援する論理付けに定まったものが 無く, 䇥常的な支援制度が存在しない点から, 起業 意欲のある事業主体にとり想定困難なコストが複数 残り，本格実施や普及定着に响けた障害の一つと なっている.

これら計画分析上の課題，および事業化に向けた 行政環境の課題を解消, 改善しつつ, カーシェアリ ングが, バス，鉄道，タクシーから構成される公共 交通システムと自家用自動車，オートバイ，自転車 との間を補完する交通機関として，例えば地域実情 に応じ柔軟な組み合わせが可能なアメリカ カリ フォルニア州の Clean Mobility Center 取組みのよう な, 総合的な視点で導入に向けた計画手法の確立, 制度の改善を進めて行くことが望まれる.

謝辞 : 本吥究は参考文献として示した各実験地域の 調查研究報告書掲載のデータや運用実績を中心とし， 一部地域については直接ヒアリングした結果に基づ き整理を行ったものである.ヒアリングや問い合わ せに回答いただいたと共に，報告書の奇贈や入手許 可をいただいた各実験地域の運用関係者の方々に簡 単ながらお礼中し上げます。

\section{付録 : Clean Mobility Center}

都市閖バスのターミナルや LRT, MRT の公共父通拋点におい て, 地域でのいわゆるラストワンマイルの交通機関として白転車, 電父スクーター，電気白動車を完備する統合的な乘り釈ぎ拠点. 車両別に既存のサービス提供企業に運用を任せている点も特徵. 今後カリフォルニア州ではこのような施設を増加させようとの 計画もあり，日本でも地域事情に纫じ多様な交通手段を取り揃え てのカーシェアリングが実施されることを願うものである.

\section{参考文献}

1）財団法人日本電動車闭協会,財団法人 自動車走行 電子技術協会: $\mathrm{EV}$ 普及のための EV 共同利用システ 么の広報・調查に関する報告書（横浜・稻城）,調查
報告書, 2002 .

2）財団法人 都市交通問題調查会,ダイハツ工業株式会 社,住及電気丁.業株式会社:大阪における電気貨物自 動車共问利用システムモデル実験報台書,調查報告書, 2001.

3）財団法人 都市交通問題調查会,ダイハツT業株式会 社,住友電気工業株式会社:電気貨物自動車共问利用 システム実験 報告書（案）,調査報告書.2002.

4）豊田市:平成 13 年度 小型電気自動車等共问利用実験 第 1 回委員会 委員会資料,調查委員会資料,2001.

5）平石 浩之,大歲 泉,中村 文彦:通勤利用における自 動車共闰利用の需要推定に関する考察, 土木計画学研 究・講演集,Vol.24,CD-ROM,No.248,2001.

6）池田久美子,大蔵 泉,中村 文彦,平石浩之:車闭共问 利用システムの適用可能性に関する基礎的䂧究,士木 計画学研究・講演集,Vol.24,CD-ROM,No.252,2001.

7）海老名市,神奈川県,建設省:平成 12 年度エコ・パーク アンドライド研究委員会 報告書,調查報告書, 2001 .

8）藤沢市,国土交通省関東地力整備局:平成 13 年度社会 実験 湘南地域での共问利用・相乗り型自動車交通社 会実験 報告書（概要版），調査報告書,2002.

9) 中山晶-朗,山本俊行,梅木亮, 北村隆-:電気自動車の 共同利用システムの効率化に関するシミュレーショ ン分析 : 京都パブリックカーシステムを事例として, 土木計画学研究・講演集, Vol.24,CD-ROM,No.250, 2001.

10）交通エコロジー・モビリティ財団:自動車共同利用シ ステムに関する調査研究 研究会報告書, 調査報告書, 2001 .

11）交通エコロジー・モビリティ財団:自動車共同利用 （カーシェアリング）社会実験 報告書,調查報告書, 2002.

12）八木麻未子,森川高行:ZEV 共同利用システムの道入 可能性に関する基礎的研究, 土木計画学研究・講演集 Vol.24,No.249,2001

13）島崎敏 - :車轌共问利用システムの車䊖配備台数の 最適化車耐共问利用システムにおける車岀の最適配 車,土木計画学研究・講演集 Vol.24,CD-ROM,No.251, 2001.

14）下原祥平,岛崎敏一䡛两共问利用システムにおける 車屾の最適配車, 土木計画学研究・講演集, Vol.24,CDROM,No.253,2001

15）岡並木:廹る”都市のスリッパ” 公共レンタカーの 挫折と復活,モビリティ文化出版,文庫本,1998.

(2003. 9. 10 受付)

大蔵泉先生におかれましては、2003 年 12 月 16 日にご逝去 されました。本稿は先生のご遗稿になりますことをここに申し 添えますとともに、先生のご冥福をお祈り申し上げます。

\section{CAR SHARINGFIEI DTESTS ONTHEFIRST STAGEAND NEEDS OFTRANSPORTPLANNING}

\section{Hiroyuki HIRAISHI, Fumihiko NAKAMURA and Izumi OKURA}

12 car sharing field tests were trialed in Japan on December 2002. Almost projects used Electric Vehicles and are high-density population areas. The results of the tests have important outcomes to car sharing planning. Car sharing planners need the model of demand estimation, and growth speed. Car sharing managers need allocating model by the flexible fee system and variable parking locations. In urban areas with high density and accessible public transport, car sharing has great potential demand. 